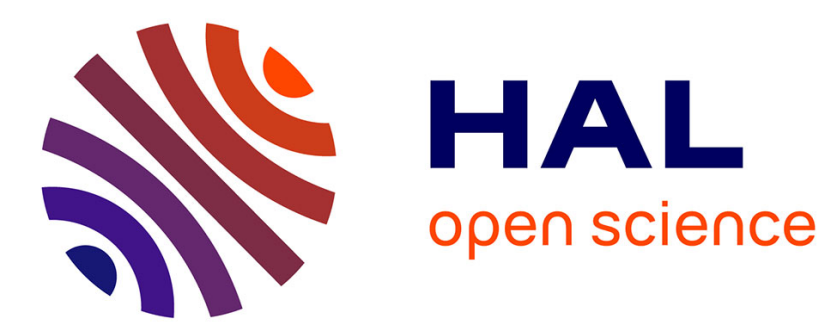

\title{
MAGNETIC BEHAVIOR OF Co2+ IONS IN SYNTHETIC MINERALS RELATED TO VIVIANITE AND LUDLAMITE
}

\author{
J. Pizarro, L. Lezama, Gérard Villeneuve, M. Arriortua, T. Rojo
}

\section{- To cite this version:}

J. Pizarro, L. Lezama, Gérard Villeneuve, M. Arriortua, T. Rojo. MAGNETIC BEHAVIOR OF Co2+ IONS IN SYNTHETIC MINERALS RELATED TO VIVIANITE AND LUDLAMITE. Journal de Physique Colloques, 1988, 49 (C8), pp.C8-2063-C8-2064. 10.1051/jphyscol:19888935 . jpa-00229213

HAL Id: jpa-00229213 https://hal.science/jpa-00229213

Submitted on 1 Jan 1988

HAL is a multi-disciplinary open access archive for the deposit and dissemination of scientific research documents, whether they are published or not. The documents may come from teaching and research institutions in France or abroad, or from public or private research centers.
L'archive ouverte pluridisciplinaire HAL, est destinée au dépôt et à la diffusion de documents scientifiques de niveau recherche, publiés ou non, émanant des établissements d'enseignement et de recherche français ou étrangers, des laboratoires publics ou privés. 


\title{
MAGNETIC BEHAVIOR OF $\mathrm{Co}^{2+}$ IONS IN SYNTHETIC MINERALS RELATED TO VIVIANITE AND LUDLAMITE
}

\author{
J. L. Pizarro $\left({ }^{1}\right)$, L. Lezama $\left({ }^{1}\right)$, G. Villeneuve $\left({ }^{1}\right)$, M. I. Arriortua $\left({ }^{2}\right)$ and T. Rojo $\left({ }^{2}\right)$ \\ ( $\left.{ }^{1}\right)$ Laboratoire de Chimie du Solide du CNRS, Université de Bordeaux I, 33405 Talence, France \\ ( ${ }^{2}$ Facultad de Ciencias, UPV, BILBAO, Spain
}

Abstract. - Members of the family of mineral vivianite $\mathrm{Fe}_{3}\left(\mathrm{PO}_{4}\right)_{2}-8 \mathrm{H}_{2} \mathrm{O}$, and ludlamite $\mathrm{Fe}_{3}\left(\mathrm{PO}_{4}\right)_{2}-4 \mathrm{H}_{2} \mathrm{O}$ involving $\mathrm{Co}^{2+}$ ions have been synthetized. $\mathrm{Co}_{3}\left(\mathrm{PO}_{4}\right)_{2}-8 \mathrm{H}_{2} \mathrm{O}$ exhibits an antiferromagnetic ordering at $6.5 \mathrm{~K}$, the nature of the interactions are discussed with respect to its crystal structure. Using hydrothermal conditions tetra and dihydrate were obtained. The ferrimagnetism observed for the tetrahydrate may be related to the ludlamite structure. A spin-flop is observed for the dihydrate at a critical field of $1 \mathrm{kG}$.

\section{Introduction}

Among the compounds with general formula $\mathrm{A}_{3}\left(\mathrm{PO}_{4}\right)_{2}-n \mathrm{H}_{2} \mathrm{O}$ three of them occur in nature as minerals when $\mathrm{A}=\mathrm{Fe}^{\mathrm{II}}$ : vivianite $(n=8)$, ludlamite $(n=4)$ and phosphoferrite $(n=3)$. These minerals have been synthetized (1) as well as other members of the homologous series corresponding to $n=2$ and 1. Their crystal structure are favorable to the presence of complex magnetic interactions with - mainly - a low dimensional character.

The magnetic properties of vivianite and ludlamite have been intensively studied by susceptibility, Mössbauer spectroscopy and specific heat measurements [1-6]. It appears that the magnetic behavior of vivianite is rather complicated, involving at least two magnetic systems which, moreover, are not independent of each other [11]. A full 3D ordering occurs below $9 \mathrm{~K}$ [2]. The behavior of ludlamite seems to be well understood with respect to its magnetic structure which consists in ferromagnetic $\mathrm{Fe}^{2+}$ trimers coupled by an antiferromagnetic intertrimer interaction [5].

Substitution of $\mathrm{Fe}^{\text {II }}$ by $\mathrm{Co}^{\text {II }}$ was expected to cause some modifications of this magnetic behavior, due to the large $g$-factor anisotropy of $\mathrm{Co}^{2+}$ in a distorted octahedral environment.

In this article we report the synthesis of hydrates $\mathrm{Co}_{3}\left(\mathrm{PO}_{4}\right)_{2}-n \mathrm{H}_{2} \mathrm{O}(n=8,4,2)$ homologous to iron compounds.

Their magnetic properties are presented and discussed with respect to the crystal structure when it is known.

\section{Synthesis and characterization}

$\mathrm{Co}_{3}\left(\mathrm{PO}_{4}\right)_{2}-8 \mathrm{H}_{2} \mathrm{O}$ was obtained from aqueous solution of cobalt sulfate and ammonium phosphate at about $70^{\circ} \mathrm{C}$. This compound was used as a precursor for the synthesis of the tetra an dihydrate using hydrothermal conditions into a sealed gold tube. Working at $160^{\circ} \mathrm{C}$ and 350 atm during 5 days we obtain a violet powder of $\mathrm{Co}_{3}\left(\mathrm{PO}_{4}\right)_{2}-4 \mathrm{H}_{2} \mathrm{O}$; increasing the temperature $\left(225^{\circ} \mathrm{C}\right)$ and the pressure $(400 \mathrm{~atm})$ small purple crystals of $\mathrm{Co}_{3}\left(\mathrm{PO}_{4}\right)_{2}-2 \mathrm{H}_{2} \mathrm{O}$ are formed as a single phase. These compounds were characterized by X-ray diffraction, thermogravimetry and IR spectroscopy.

\section{Magnetic properties}

$\mathrm{Co}_{3}\left(\mathrm{PO}_{4}\right)_{2}-8 \mathrm{H}_{2} \mathrm{O}$. - The crystal structure of $\mathrm{Co}_{3}\left(\mathrm{PO}_{4}\right)_{2}-8 \mathrm{H}_{2} \mathrm{O}$ is isotype to that of vivianite $\mathrm{Fe}_{3}\left(\mathrm{PO}_{4}\right)_{2}-8 \mathrm{H}_{2} \mathrm{O}$ determined by MORI and ITO [7] which is repressented in figure 1 .

Its magnetic susceptibility follows, at high temperature, a Curie-Weiss law $\chi=C / T-\theta$ with $c=3.20$ per $\mathrm{Co}^{2+}$ and $\theta=-11 \mathrm{~K}$. The Curie constant value is in good agreement with those generally found for $\mathrm{Co}^{2+}$ ions in distorted octahedral site. At low temperature a $3 \mathrm{D}$ antiferromagnetic ordering occurs at $6.5 \mathrm{~K}$, due to a complex coupling involving at least four exchange interactions:

- a direct interaction involving $\mathrm{d}_{x y}$ orbitals of $\mathrm{Co}^{2+}$ in dimeric sites (antiferromagnetic);

- a superexchange intradimer interaction via oxygen involving $\mathrm{d}_{x^{2}-y^{2}}$ orbitals (ferromagnetic);
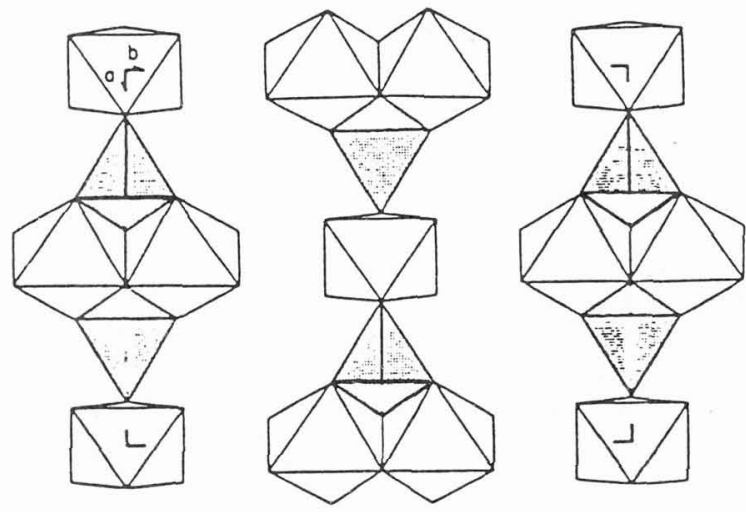

Fig. 1. - Crystal structure of vivianite. 
- a superexchange interdimer interaction via $\mathrm{PO}_{4}$ group, $\mathrm{d}_{x^{2}-y^{2}}-\mathrm{PO}_{4}-\mathrm{d}_{z^{2}}$ (antiferromagnetic);

- a superexchange interaction via $\mathrm{PO}_{4}$ group between cobalt in dimers and monomers, $\mathrm{d}_{z^{2}}-\mathrm{PO}_{4}-\mathrm{d}_{z^{2}}$ (antiferromagnetic).

The sign of the different coupling are obtained following Anderson-Goodenough-Kanamori rules [8-10].

$\mathrm{Co}_{3}\left(\mathrm{PO}_{4}\right)_{2}-4 \mathrm{H}_{2} \mathrm{O}$. - The structure of the tetrahydrate $\mathrm{Co}_{3}\left(\mathrm{PO}_{4}\right)_{2}-4 \mathrm{H}_{2} \mathrm{O}$ is unknown. Nevertheless the study of the magnetic susceptibility clearly shows a ferrimagnetic ordering at $4.5 \mathrm{~K}$ (Fig. 2). In the homologous mineral ludlamite $\mathrm{Fe}_{3}\left(\mathrm{PO}_{4}\right)_{2}-4 \mathrm{H}_{2} \mathrm{O}$, the magnetic structure consists in ferromagnetic trimers of $\mathrm{Fe}^{2+}$ with an antiferromagnetic intertrimers coupling. If we assume that the structure of the cobalt phosphate tetrahydrate is related to that of ludlamite, the observed ferrimagnetism behavior can be explained by the strong anisotropy of the $\mathrm{Co}^{2+} \mathrm{g}$-factor, giving rise to uncompensated magnetic moments.

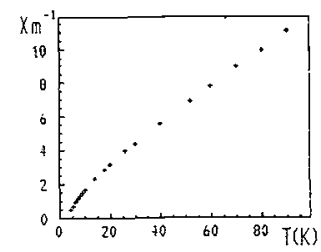

Fig. 2. - Magnetic behavior of $\mathrm{Co}_{3}\left(\mathrm{PO}_{4}\right)_{2}-4 \mathrm{H}_{2} \mathrm{O}$.

$\mathrm{Co}_{3}\left(\mathrm{PO}_{4}\right)_{2}-2 \mathrm{H}_{2} \mathrm{O}$. - The magnetization of the dihydrate $\mathrm{Co}_{3}\left(\mathrm{PO}_{4}\right)_{2}-2 \mathrm{H}_{2} \mathrm{O}$ exhibits a rather complex behavior (Fig. 3). Below $11 \mathrm{~K}$ its field dependence shows an anomalous increase between 1 and $10 \mathrm{kG}$. This indicates a $\mathrm{Co}^{2+}$ spin-flop at a critical field $H_{\mathrm{c}} \simeq$ $1 \mathrm{kG}$ in the $3 \mathrm{D}$ ordered region. The susceptibility was measured at fields lower than $1 \mathrm{kG}$ in order to avoid the

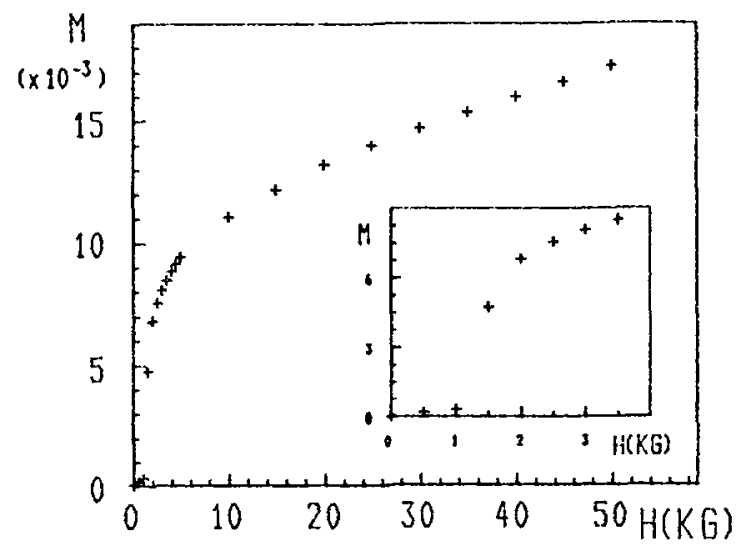

Fig. 3. - Magnetization of $\mathrm{Co}_{3}\left(\mathrm{PO}_{4}\right)_{2}-2 \mathrm{H}_{2} \mathrm{O}$ as a function of magnetic field at $4.5 \mathrm{~K}$. effects of the spin flop. At high temperature it follows a Curie-Weiss law with $C=2.77$ emu per $\mathrm{Co}^{2+}$ and $\theta=-42 \mathrm{~K}$. Considering the behavior of the product $\chi T$ vs. $T$ (Fig. 4) one can observe three domains.

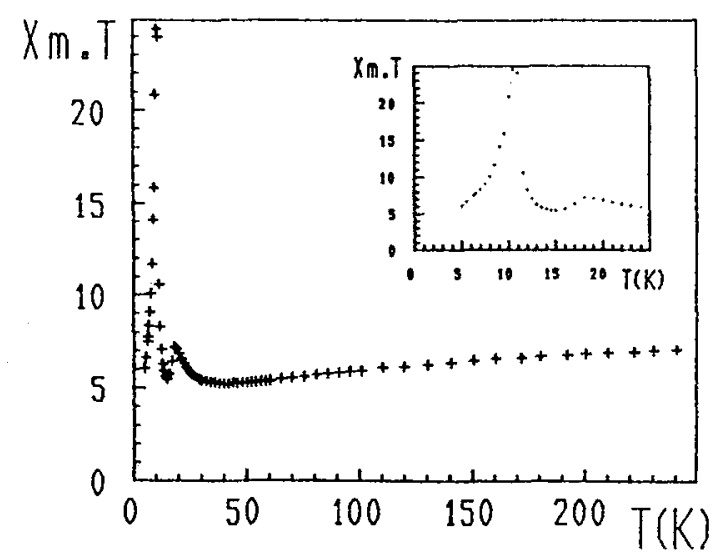

Fig. 4. - Experimental $\chi . T$ values of $\mathrm{Co}_{3}\left(\mathrm{PO}_{4}\right)_{2}-2 \mathrm{H}_{2} \mathrm{O}$ in the $4-250 \mathrm{~K}$ range.

Above $18 \mathrm{~K}$, the evolution of $\chi T$ is typical of low dimensional ferrimagnetic behavior (cluster, 1D ?). Below $11 \mathrm{~K}$ a 3D antiferromagnetic ordering occurs. The behavior between 11 and $18 \mathrm{~K}$ is not yet clearly understood.

\section{Acknowledgements}

We thank the Basque Government/Eusko Jaurlaritza for a doctoral Fellow-ship to 2 of us (J.L.P. and L.L.).

[1] Mattievich, E. and Danon, J., J. Inorg. Nucl. Chem. 39 (1977) 569-580.

[2] Meijer, H. C., Van Den Handel, J., Frikkee, E., Physica 34 (1967) 475-483.

[3] Meijer, H. C., Giesen, J. J. and Van Den Handel, J., Physica 38 (1968) 227-232.

[4] Meijer, H. C., Adrair, III T. W. and Van Den Handel, J., Physica 38 (1968) 233-240.

[5] Abrahams, S. C., J. Chem. Phys. 44 (1966) 22302237.

[6] Forstat, H., Love, N. D., Mac Elearney, J. N. and Butterworth, G. J., Phys. Rev. 1 (1970) 30973100.

[7] Mori, H. and Ito, I., Acta Cryst. 3 (1950) 1-6.

[8] Anderson, P. W., Phys. Rev. 13 (1958) 1492.

[9] Goodenough, J. B., Magnetism and the Chemical bound (Intercience Publ., New York) 1963.

[10] Kanamori, J., Phys. Chem. Solids 10 (1958) 87.

[11] Forsyth, J. B., Johnson, C. E., Wilkinson, C., J. Phys. C: Solid St. Phys. 3 (1970) 1127-1139. 